\title{
Do cave orb spiders show unique behavioural adaptations to subterranean life? A review of the evidence
}

\author{
Thomas Hesselberg $^{\mathrm{a}, \mathrm{b}, \mathrm{c}, *}$, Daniel Simonsen ${ }^{\mathrm{a}}$ and Carlos Juan $^{\mathrm{c}, \mathrm{d}}$ \\ ${ }^{a}$ Department of Zoology, University of Oxford, South Parks Road, Oxford, OX1 3PS, UK \\ ${ }^{\mathrm{b}}$ Department for Continuing Education, University of Oxford, Wellington Square, Oxford, \\ OX1 2JA, UK \\ ${ }^{\mathrm{c}}$ Department of Biology, University of the Balearic Islands, 07071 Palma de Mallorca, \\ Spain \\ ${ }^{d}$ IMEDEA (CSIC-UIB), Mediterranean Institute for Advanced Studies, Esporles, 07190, \\ Spain \\ *Corresponding author's e-mail address: Thomas.hesselberg@zoo.ox.ac.uk
}

Received 19 November 2018; initial decision 8 May 2019; revised 19 May 2019; accepted 21 May 2019; published online 1 July 2019

\begin{abstract}
Interest for subterranean biology has risen sharply in recent years due to the simplicity of the cave environment. However, most studies have focussed on morphology with few studies looking at behaviour. The cave orb spiders show some unique behavioural adaptations compared to other orb spiders, including rudimentary orb webs, off-web foraging and a complex life cycle with a surface phase. Here, we compare these behavioural adaptations in the European Meta menardi and Meta bourneti to similar behaviours in surface-dwelling orb spiders. We find that current data suggest (1) an extreme reduction in the number of frame threads, (2) evidence of capturing non-flying prey, but not necessarily evidence for off-web foraging and (3) dispersal through a surface-dwelling life stage, but with data lacking on the role of ballooning and their return to caves. We conclude that Meta spiders have potential as model organisms for studies on behavioural adaptations and flexibility.
\end{abstract}

\section{Keywords}

behavioural flexibility, cave spiders, dispersal, orb web geometry, prey capture, Tetragnathidae. 


\section{Introduction}

Subterranean habitats are some of the least studied terrestrial ecosystems and we have little current knowledge on the natural history and behaviour of the majority of organisms found in them. However, interest has grown in recent years and cave ecosystems are now generally recognised as natural ecological and evolutionary laboratories due to the isolation of their organisms, the fewer and more simple biotic interactions due to low species richness and abundance and the number of similar morphological adaptations found in a range of organisms (Poulson \& White, 1969; Pipan \& Culver, 2013; Mammola, 2018). Cave ecosystems are characterised by stable environmental conditions, low light levels and as a consequence usually no primary production and they are as a result generally nutrients poor (Culver \& Pipan, 2009). Caves though are not homogenous in their ecology, but can be divided into three zones. The entrance zone is generally defined as the area immediately near the entrance which is reached by direct sunlight and is characterised by being relatively nutrient rich due to the number of epigean animals that accidentally enter the cave. The twilight zone is characterised by very low light levels and a much lower abundance of organisms. Finally, the dark zone starts where light can no longer be detected by the human eye and stretches until the end of the cave. This is usually the largest and most nutrient poor zone, but it is also where the largest number of cave adapted species can be found. Following the traditional speleological terms (Sket, 2008), organisms with adaptations, in almost all cases this refers to morphological adaptations, to caves and other subterranean habitats are classified as troglomorphs. All troglomorphs are also troglobionts, which are organisms that are obligatorily associated with subterranean habitats for all life stages. In contrast, troglophiles usually spend some time outside them, while trogloxenes are visitors to the subterranean habitat, but spend most of their life outside.

Unsurprisingly, spiders are generally well represented in caves given their exaptations to subterranean life including, for most families, low reliance on vision and low metabolism allowing them to survive months without feeding (Foelix, 2011). There are more than 1000 species of troglobiont spiders and at least an equal number of troglophile spiders belonging to 48 families out of 47000 described species of spiders in 113 families (Mammola \& Isaia, 2017). In Europe, 195 troglobiont and 291 troglophile species are currently recognised in 22 families (Mammola et al., 2017a). The most species 
rich families are Linyphiidae with 222 subterranean species (including the almost exclusively troglobiont genera Centromerus and Troglohyphantes), Dysderidae with 56 species and the predominantly subterranean Nesticidae with 50 species (Mammola et al., 2017a).

Surprisingly, given the scarcity of flying insects, orb spiders in the family Tetragnathidae (genera Meta and Metellina) are common in European caves, although all are troglophiles and mainly limited to the twilight zone (Mammola \& Isaia, 2014). Orb webs are two-dimensional highly organised structures consisting of radii running from the central hub to the frame and overlaid by the capture spiral that are adapted to intercept and retain flying insects (Eberhard, 1990b). Thus, the orb web can be viewed as a physical record of the spider's foraging behaviour, which together with the ease of getting spiders to construct orb webs in the laboratory and the highly quantifiable nature of the web have made orb spiders and their webs model organisms for the study of a wide range of different behaviours (Zschokke $\&$ Herberstein, 2005; Hesselberg, 2015). Orb spiders show a remarkable behavioural flexibility and modify their web-building and foraging behaviour in response to a wide range of internal and external factors including microclimatic conditions (Vollrath et al., 1997; Liao et al., 2009; Turner et al., 2011; Wu et al., 2013), prey capture experience (Pasquet et al., 1994; Heiling \& Herberstein, 1999; Blamires, 2010), leg loss (Vollrath, 1987; Pasquet et al., 2011) and spatial constraints in the micro-habitat (Krink \& Vollrath, 2000; Barrantes \& Eberhard, 2012; Harmer et al., 2012; Hesselberg, 2013). Despite their relatively simple and small brains, they show impressive cognitive abilities (Hesselberg, 2015; Japyassu \& Laland, 2017) including spatial learning of prey impacts (Nakata, 2013), alertness to web damage and faster repairs in windy conditions (Tew et al., 2015), simple numerosity (Rodríguez et al., 2015), and memories of previous web-building behaviour (Eberhard, 1988) and prey capture (Rodríguez \& Gamboa, 2000; Rodríguez et al., 2013).

We know almost nothing about the behaviour of any cave spider (Mammola \& Isaia, 2017), but the cave orb spiders have been alleged to possess a number of unique behavioural adaptations to subterranean life not found in terrestrial orb spiders. Here, we review the evidence for adaptive modifications of the standard orb web and for unusual foraging as well as the highly interesting life cycle and dispersal behaviour and contrast it to closely related epigean tetragnathid spiders. Our aim is to highlight the research potential of studying the behaviour of these large, conspicuous and relatively abundant, but overlooked, troglophiles. 


\section{Cave orb spiders}

The largest family of orb spiders is Araneidae followed by Tetragnathidae and the cribellate Uloboridae (Foelix, 2011), but the only orb spider family with described representatives in the subterranean environment is Tetragnathidae. This is a large family with 987 species in 46 genera (Kallal \& Hormiga, 2018). Currently, 7 cave-dwelling spiders are known in the genus Meta and two in Metellina (Table 1), although it is likely that there are subterranean species in other tetragnathid genera; for example, Orsinome has been reported in caves in Tasmania (Eberhard, 1992). The genus Meta currently has 23 species, but as it has been treated as the 'waste-bin' of the Metaine subfamily this is likely to change. In 2018 alone, 11 species were transferred from Meta to other genera (mainly Metellina and Tetragnatha) (Kallal \& Hormiga, 2018; Marusik \& Larsen, 2018). Given that Marusik \& Larsen (2018) use a relatively large size as a criterion for including species in Meta (and in Metellina), many of the Asian species are likely incorrectly placed in Meta (Table 1). Meta meruensis for example most likely belongs in the genus Leucauge (Marusik \& Larsen, 2018). In general, we know very little about the natural history of most Meta spiders and for many species, we have not even been able to determine if they are cave-dwellers or not (Table 1). Although most of the species with known habitats are subterranean, this appears not to be a key characteristic of the genus as M. stridulans is an endemic of Madeira, where it inhabits laurel forests (Crespo et al., 2014).

In this review, we will focus on the two species of Meta spiders that we know most about - the common European cave orb spiders $M$. menardi and M. bourneti - with a brief mention of Metellina merianae, which, together with M. villersi (Denis, 1955), is the only known Metellina regularly found in caves. Meta bourneti (Simon, 1922) (Figure 1) is a large spider (the male is $10-13 \mathrm{~mm}$ and the female $14-16 \mathrm{~mm}$ in total length) with a dark brown cephalothorax and a usually uniformly yellowish brown to black abdomen. It is classified as a troglophile and usually found in the twilight zone of caves, where it builds relatively small orb webs compared to closely related epigean tetragnathids. It is widely distributed in southern Europe and around the Mediterranean including northern Africa. It is also found in southern parts of the UK, where it is likely to be an introduced species (Mammola, 2017). Meta menardi Latreille, 1804 (Figure 1), also sometimes referred to as the European cave spider, is a large spider (the male is $10-12 \mathrm{~mm}$ and the female $12-15 \mathrm{~mm}$ in total length). It has a red-brown cephalothorax and a 
T. Hesselberg et al. / Behaviour 156 (2019) 969-996

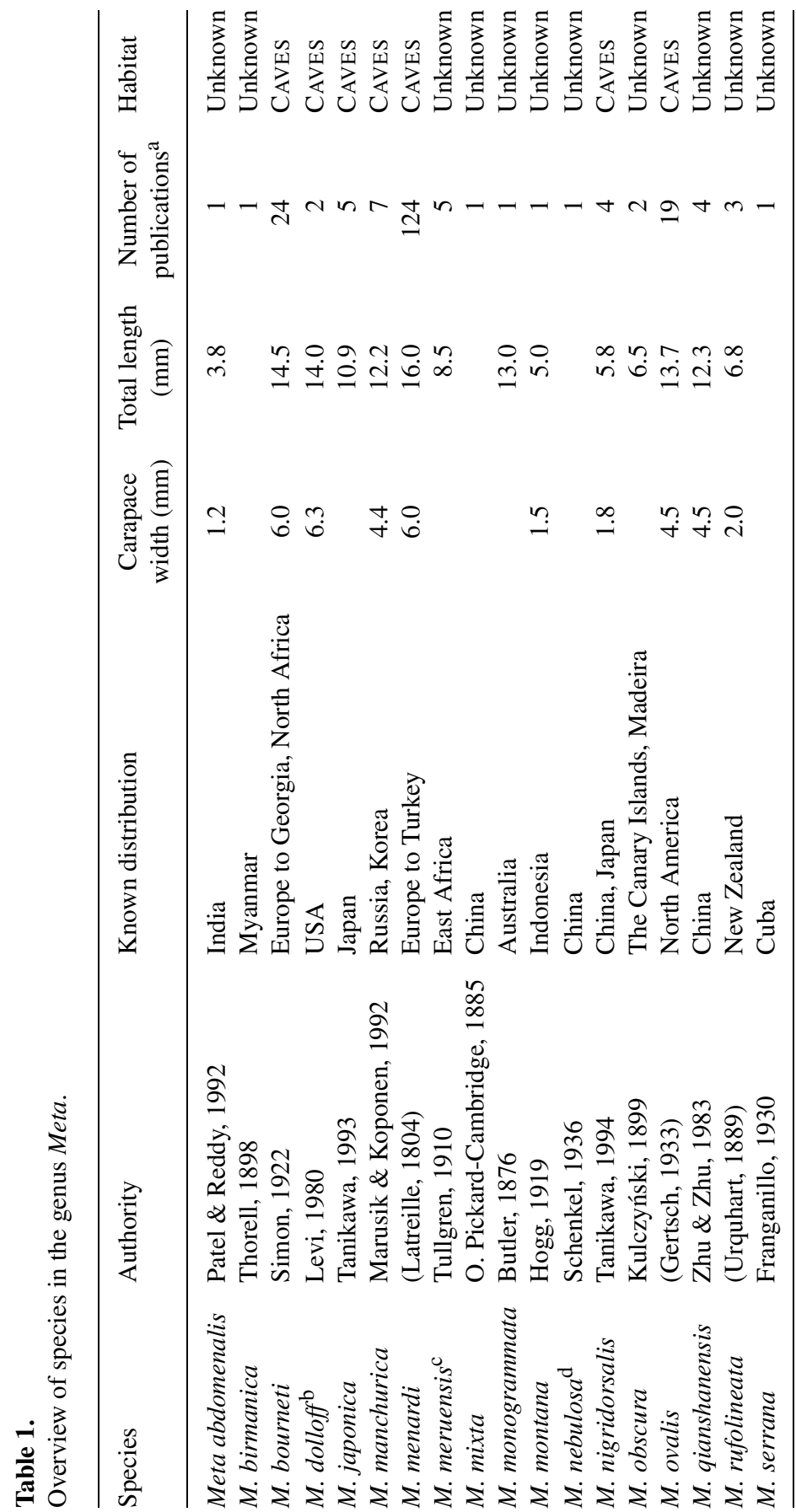




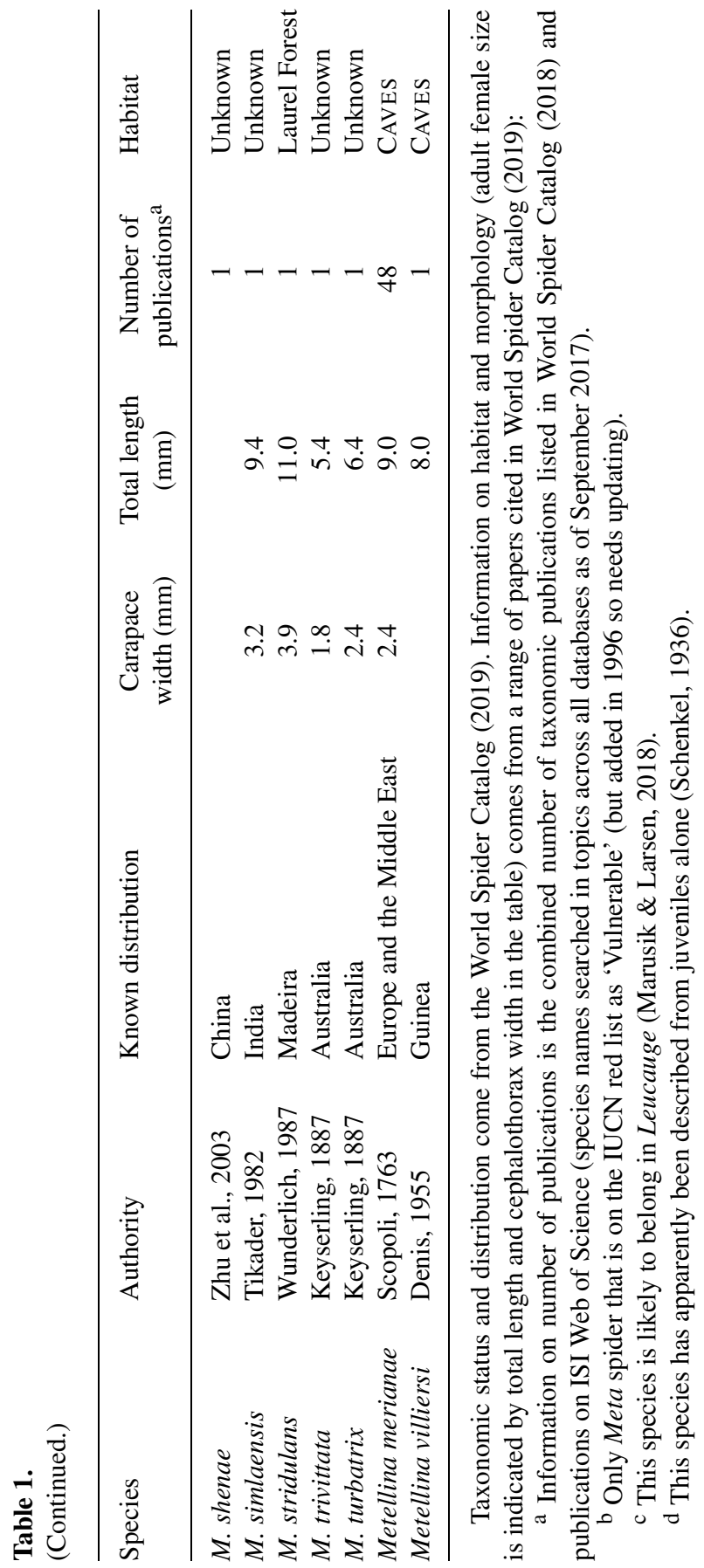


Meta bourneti

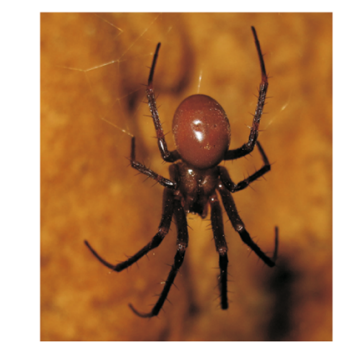

Meta menardi
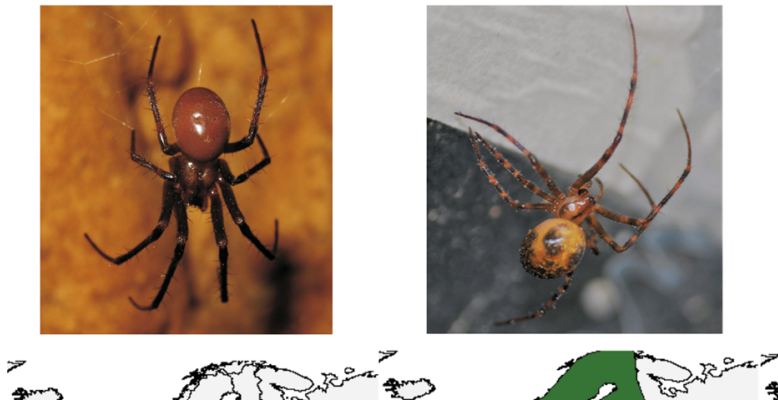

\section{Metellina merianae}
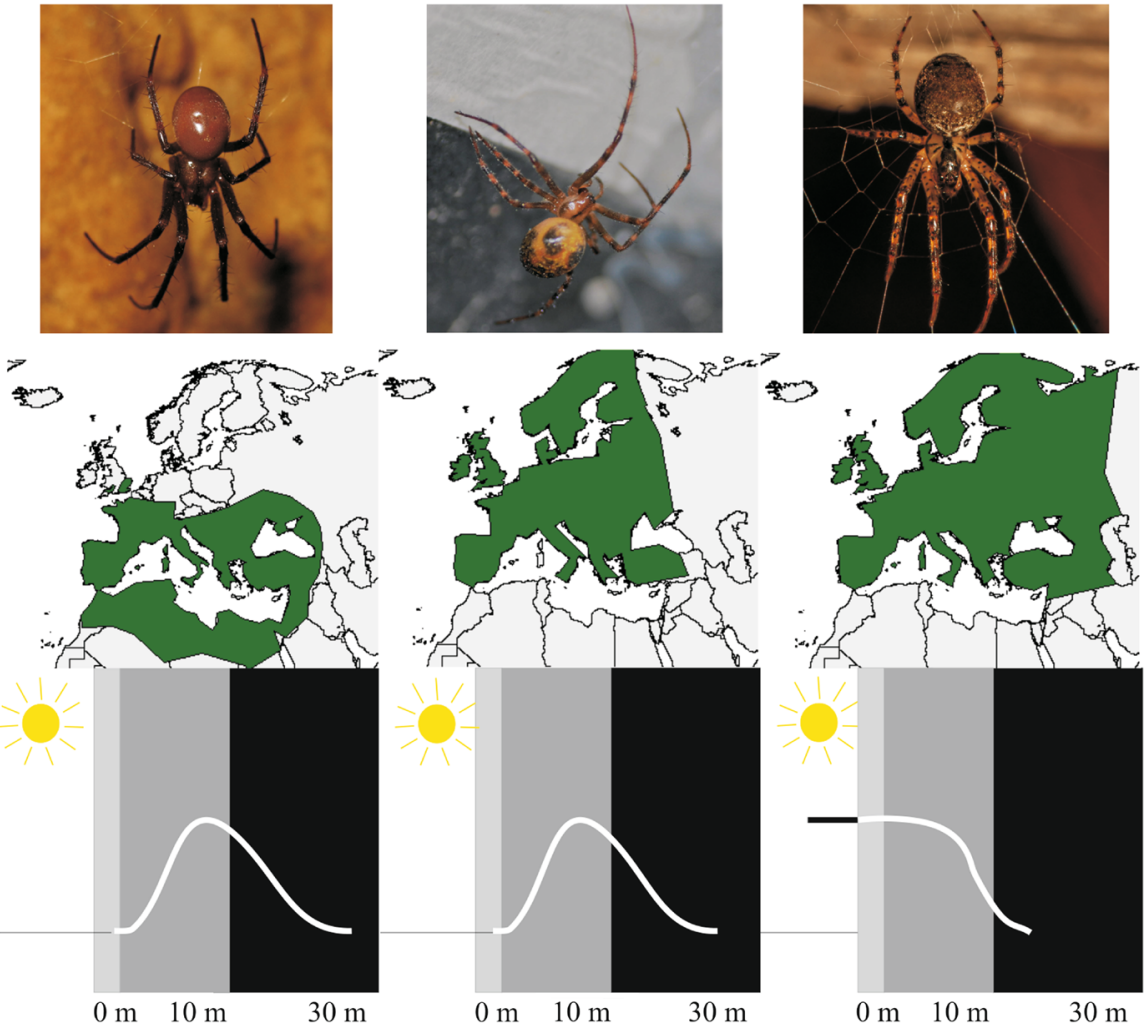

Figure 1. Distribution of the European cave spiders (2nd row: known distributions taken from the World Spider Catalogue (2018) and from Araneae - Spiders of Europe (Nentwig et al., 2018)) and cave location preference (3rd row: the entrance zone is the first few metres inside the cave (light grey), the twilight zone (dark grey) stretches 10-15 m, depending on cave structure, before the dark zone starts (black)). 1st column: Meta bourneti Simon, 1922. Photo with permission from Didier Petot. 2nd column: Meta menardi Latreille, 1804. Photo with permission from Thomas Hesselberg. 3rd column: Metellina merianae Scopoli, 1763. Photo with permission from Richard McMellon.

yellow abdomen with darker stripes or large spots. Similarly, to M. bourneti, $M$. menardi is a troglophile that is predominantly found in the twilight zone of caves, although it is also recorded from other dark places including mines, cellars, manholes and in crevices and boulder fields (Růžička et al., 2013). It is considered common across Europe including Scandinavia up to near the Arctic circle and as far east as Turkey. Metellina merianae Scopoli, 1763 (Figure 1) is a medium sized spider (the male is $7-8 \mathrm{~mm}$ and the female 
6-10 $\mathrm{mm}$ in total length) with a yellow-green cephalothorax and a greenbrown abdomen overlaid with a darker chequer pattern. It is found in the entrance zone and the first part of the twilight zone in caves and other dark places, but unlike the two Meta species, it can also be found in terrestrial habitats including damp and shady woodland areas. There is no evidence of any behavioural adaptions to subterranean habitats in this species. It is common and widespread in Europe extending as far east as Caucasus and Iran.

Interestingly, although there is a large overlap in the distribution of all three species (Figure 1), none of them are sympatric on the micro-scale. Instead they show a significant degree of niche separation. Meta menardi and Meta bourneti are never found in the same cave (Mammola \& Isaia, 2014). M. bourneti has a relatively wide tolerance of microclimatic conditions, whereas $M$. menardi has a relatively narrow range preferring cooler caves with high humidity and in the favourable habitats $M$. menardi apparently outcompetes $M$. bourneti (Mammola \& Isaia, 2014). On the other hand, Meta menardi are found to co-occur with Metellina merianae with limited spatial niche separation, although $M$. merianae is usually found closer to the cave entrance than M. menardi (Novak et al., 2010). Instead the two species show a significant temporal niche separation with the number of juveniles of $M$. merianae showing large peaks at the end of the summer, whereas juvenile abundance of $M$. menardi is more evenly distributed with minor peaks in winter and spring (Novak et al., 2010). Throughout the rest of this review we compare aspects of the behaviour of Meta cave spiders with those of terrestrial tetragnathids; especially with the closely related Metellina (Alvarez-Padilla \& Hormiga, 2011; Kallal \& Hormiga, 2018; see Figure 2).

\section{The orb web: behavioural adaptation or flexibility?}

The orb web is one of the most conspicuous and geometrically ordered structures in nature. As mentioned in the introduction, the archetypical orb web consists of a central hub from which radii radiate outwards towards the frame and upon which the capture spiral is overlain (Figure 3A). This general structure is conserved across all the major orb-spider families, but with variation in the detailed geometry and in the material properties of the different silk types used (Vollrath \& Selden, 2007; Sensenig et al., 2010). There are, however, minor differences among the families (Foelix, 2011). Tetragnathid webs, in contrast to araneid webs, tend not to have any threads in 


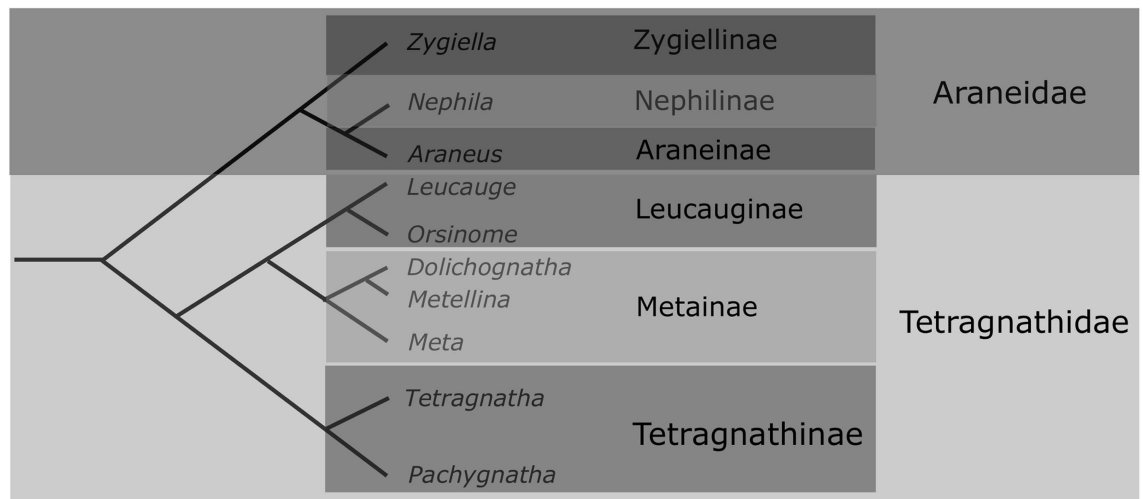

Figure 2. Simplified phylogenetic tree of orb web spiders in the family Araneidae and Tetragnathidae highlighting subfamilies and genera of interest for the discussions presented in this paper. Adapted from the maximum likelihood analysis (Figure 1) of Kallal \& Hormiga (2018).

the centre of their hubs and tend to be more horizontally inclined with the woodland species Metellina mengei, for example, having webs that varied in inclination with horizontal from 5 to $85^{\circ}$ (Tew \& Hesselberg, 2018). The

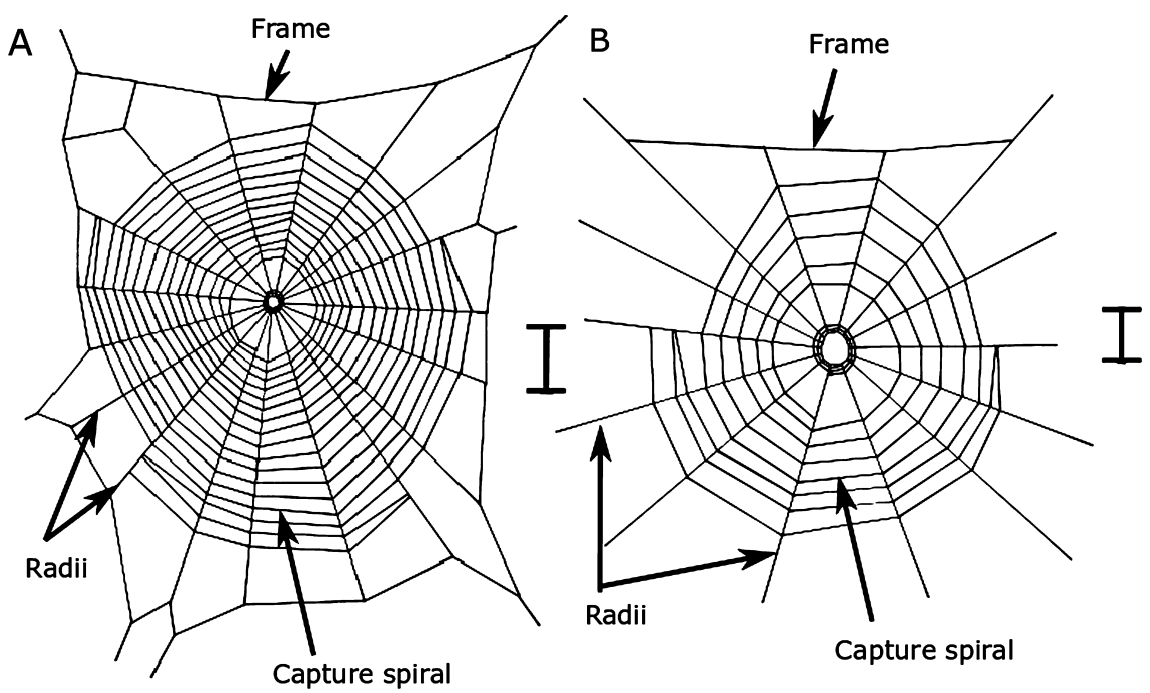

Figure 3. Schematic drawing of orb webs based on measurements of typical webs (Simonsen $\&$ Hesselberg, data not shown). Arrows points to frame threads, radii and the capture spiral. The vertical scale bars at the righthand side of each web is $20 \mathrm{~mm}$ in length. (A) Metellina mengei web; (B) Meta menardi web. 
differences are not immediately apparent from a casual glance, but webs of Meta menardi and M. bourneti differ from the typical orb web in that they have very few frame threads (Figure 3B). The web is also smaller and less complex with fewer radii and capture spiral turns, which have led some authors to conclude that the web is rudimentary in nature and does not play any role in prey capture (Eckert \& Moritz, 1992; Smithers, 1996). This has been refuted by Fritzen \& Kaponen (2011), who observed a M. menardi catching a mosquito that flew into its web. In the Japanese cave spider Meta japonica, prey was also caught when intercepted by the web in similar manner to epigean orb spiders (Yoshida \& Shinkai, 1993). A comparative quantitative study (Simonsen \& Hesselberg, data not shown) on the web geometry of M. menardi and epigean tetragnathids demonstrated that while $M$. menardi webs have fewer radii (mean $\pm \mathrm{SE}: 14.9 \pm 3.1, N=23$ ) than Metellina mengei (mean $\pm \mathrm{SE}: 18.6 \pm 2.9, N=29$ ) (Figure 3), their webs have almost the same number of radii as the webs of another common northern European epigean tetragnathid; Tetragnatha montana (mean \pm SE: $15.9 \pm 2.3$, $N=37$ ). M. menardi webs did have fewer capture spiral turns (mean $\pm \mathrm{SE}$ : $6.1 \pm 2.0, \mathrm{~N}=23$ ) than both $M$. mengei (mean $\pm \mathrm{SE}: 15.0 \pm 3.6, N=29)$ and T. montana webs (mean $\pm \mathrm{SE}: 14.0 \pm 3.1, \mathrm{~N}=38$ ). This is, however, in contrast to the Asian cave orb spider Meta japonica, which built larger webs but with a similar number of radii (mean \pm SE: Number of radii: 17.0 $\pm 4.3, N=47$ and number of capture spirals: $14.6 \pm 5.3, N=42$ ) (Yoshida \& Shinkai, 1993).

Thus, while the overall web geometry of Meta is probably not an adaptation to the subterranean habitat, the omission of frame threads is highly unusual. The terrestrial tetragnathids, $M$. menge $i$ and T. montana had an almost 1:1 ratio between the number of frame threads and the number of radii, while $M$. menardi and M. japonica in contrast had ratios of 1:10 and 1:15, respectively (Yoshida \& Shinkai, 1993; Simonsen and Hesselberg, data not shown). Most radii attach directly to the cave wall or ceiling, rather than to frame threads with the web then attaching to the substrate with a few long anchor threads as is usually the case in orb spiders (Zschokke, 2000; Foelix, 2011; Hesselberg, 2013). As discussed in the next section, this might be an adaptation to capture walking prey using the radii as trip wires to alert the spider of passing prey. However, most Meta webs are built across small crevices in the cave wall or ceiling with the capture spiral rarely being far from the substrate, so it is possible that spiders face spatial constraints 
when constructing their webs. Orb spiders generally adjust to spatial constraints in the laboratory by changing the shape of their webs and reduce the spacing between spiral turns, but otherwise keep the web structure intact (Ades, 1986; Vollrath et al., 1997; Krink \& Vollrath, 2000). However, the araneid Eustala illicita sometimes appeared to attach radii directly to the frame wall when building webs in narrow, elongated vertical frames in the laboratory (Hesselberg, 2013). Similarly, the tetragnathid Leucauge argyra was observed to occasionally attach radii directly to small-diameter cylindrical tubes (Barrantes \& Eberhard, 2012). It is therefore possible that Meta spiders are just showing extreme behavioural flexibility to spatial constraints rather than showing specific adaptations to the cave environment. This is supported by observations that when $M$. menardi did build frame threads, these were constructed in the parts of the web that was furthest away from the cave wall (D. Simonsen, Pers. Obs.); potentially suggesting that the frame building behaviour occurs when $M$. menardi are released from the spatial constraints of the small crevice. None of the epigean spiders tested in the laboratory, however, showed the extreme reduction in frame threads seen in Meta spiders, so it remains most likely that this is an adaptation rather than behavioural flexibility. Manipulative laboratory experiments of Meta building in environments of varying spatial complexity, following the guidelines given by Zschokke \& Herberstein (2005), are needed to conclusively answer this question. Such experiments might also shed light on the webbuilding behaviour of Meta, which has not been described so far. Given that both araneid and tetragnathid orb spiders construct their frame threads at the same time as they construct the radii (Eberhard, 1990a; Zschokke \& Vollrath, 1995; Foelix, 2011), it would be interesting to see how Meta spiders have adapted the otherwise stereotypic building sequence to eliminate frame thread construction. They could also reveal what potential factors are involved when Meta spiders do build frame threads, particularly whether this behaviour is influenced by the environment.

\section{Foraging behaviour}

The main function of the orb web is to intercept and retain flying insects (Eberhard, 1990b). To do so, the impact energy is dissipated through deformations of primarily the radii and in most cases through aerodynamic damping on the whole vibrating web (Lin et al., 1995; Sensenig et al., 2012; 
Zaera et al., 2014), while the glue droplets on the capture spiral and its remarkable extensibility, retain the prey in the web long enough for the spider to run out and catch it (Nentwig, 1982; Swanson et al., 2007; Sahni et al., 2010). During prey interceptions, the spider relies on vibrational information relayed through the radii to give it information on prey location and prey size (Klärner \& Barth, 1982), before rushing out from the hub (or via a signal thread from its retreat) towards the prey (Hesselberg \& Vollrath, 2006; Turner et al., 2011). Depending on the size and defensive capabilities of the prey, the spider either directly bites the prey (small, harmless prey) or first wraps the prey in additional silk before approaching for the bite (larger, potentially dangerous prey) (Robinson et al., 1969; Hénaut et al., 2001, 2014). Similar, behavioural flexibility was shown by the Japanese cave spider Meta japonica in response to dipterans and ants being thrown into the web (Yoshida \& Shinkai, 1993). It has though been claimed that Meta orb webs are rudimentary and do not play a role in prey capture and that spiders instead engage in off-web foraging to capture prey such as snails and myriapods, which crawl on the cave wall (Eckert \& Moritz, 1992; Smithers, 1996).

The Meta orb web, however, clearly can function as a trap as the Japanese cave orb spider example above shows (see also Fritzén \& Koponen, 2011). Studies of the prey actually consumed by spiders find that while dipterans (especially mosquitoes, gnats and crane flies), as in other orb spiders, is a major prey type (accounting for between 7 and 39\% of all prey), between 36 and $69 \%$ of prey does not fly including snails, arachnids and myriapods (Table 2). This value may be even higher as some of the prey classified as flying in Table 2, spend more time resting or walking on the cave wall than flying (L. Knight, pers. obs.). It is unlikely that prey would fall from the cave ceiling into the web in such numbers, so the Meta spiders must engage in unusual foraging behaviour. However, we have been unable to find any published recordings or observations of actual off-web hunting, or of spiders with prey not on an orb web. This is of course not evidence that the behaviour does not take place. It could be rare and short in duration, and as M. menardi has been found to be more active at night (Mammola \& Isaia, 2018), offweb foraging might take place at times when cave biologists are unlikely to be there to observe it. If it does take place, it would constitute a very interesting departure from normal foraging behaviour in orb spiders as the standard prey capture behaviour described above would not work outside 
Table 2.

Prey consumption of the cave orb spider Meta menardi.

\begin{tabular}{|c|c|c|c|}
\hline Prey & Smithers $(2005 a)^{a}$ & Novak et al. $(2010)^{\mathrm{b}}$ & C. Terrell-Nield (unpubl) \\
\hline Location & Mine, UK & Caves, Slovenia & Caves, UK \\
\hline \multicolumn{4}{|l|}{ Flying } \\
\hline Diptera $^{\mathrm{a}}$ & $7 \%$ & $30 \%$ & $39 \%$ \\
\hline Caddisflies & $16 \%$ & $0 \%$ & $10 \%$ \\
\hline Hymenopterans & $0 \%$ & $0 \%$ & $0 \%$ \\
\hline Lepidoptera & $2 \%$ & $0 \%$ & $15 \%$ \\
\hline Other ${ }^{\mathrm{b}}$ & $6 \%$ & $1 \%$ & $0 \%$ \\
\hline Total flying & $31 \%$ & $31 \%$ & $64 \%$ \\
\hline \multicolumn{4}{|l|}{ Non-flying } \\
\hline Slugs and snails & $19 \%$ & $0 \%$ & $1 \%$ \\
\hline Myriapods ${ }^{c}$ & $36 \%$ & $11 \%$ & $20 \%$ \\
\hline Isoptera & $0 \%$ & $5 \%$ & $2 \%$ \\
\hline Arachnids ${ }^{\mathrm{d}}$ & $7 \%$ & $43 \%$ & $5 \%$ \\
\hline Beetles & $7 \%$ & $10 \%$ & $8 \%$ \\
\hline Total non-flying & $69 \%$ & $69 \%$ & $36 \%$ \\
\hline
\end{tabular}

Diptera mainly includes fungus gnats and mosquitoes; other flying prey includes lacewings, crickets and unidentified remains; Myriapods mainly includes millipedes; and Arachnids mainly includes spiders and harvestmen.

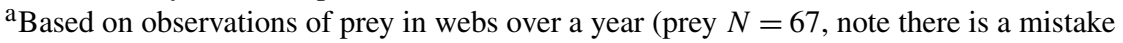
in the total number of prey and hence of the relative frequencies given in Table 1 of Smithers, 2005a).

${ }^{b}$ Based on observations of prey in webs from 1977 to 2002 . Relative frequencies were reported, so to estimate percentage, the following number of prey (mean value of band) was assumed for each of the study's frequency bands: $1=1$ prey, $2=6$ prey, $3=20$ prey, $4=$ 40 prey and this was then expressed as a percentage (total prey $N=156$ ).

${ }^{\mathrm{c}}$ Based on a combination of direct observations of prey in webs and analysis of prey remains dropped from the web and intercepted by nets placed underneath the web in autumn.

of a web. Instead Meta spiders would have to display the more ancestral stalking or sit-and-wait behaviour found in web-less spiders (Foelix, 2011). However, there are examples of tetragnathid species not building webs as adults including the aphid specialist Pachygnatha degeeri (Madsen et al., 2004; Harwood et al., 2005) and others in the same genus (Alvarez-Padilla \& Hormiga, 2011), but nothing is known about their detailed prey capture behaviour. They are though often found wandering on the ground and are frequently captured in pitfall traps in agricultural land (Meek et al., 2002; Alvarez-Padilla \& Hormiga, 2011), so presumably actively search for prey. 
An alternative explanation to off-web foraging relates to the behavioural adaptations of the web itself as discussed in the previous section. The radii that directly attach to the cave wall could act as trip lines alerting the spider to passing prey that it can then rush out along the radii to attack. This would be similar to the foraging behaviour of some trapdoor spiders including Nemesia meridionalis (Family Nemesiidae) and Idiosoma rhaphiduca (Family Idiopodae) that construct signal or trip lines radiating out from the opening of their burrow (Buchli, 1969). When an invertebrate triggers one of the lines by touching it, the ensuing vibrations cause the spider to rush out of its burrow and seize the prey. A similar use of the radii as signal or trip lines may be a more likely explanation for prey capturing in Meta spiders than off-web foraging. It explains why no observations of the behaviour exist and partly explains the elimination of frame threads as their higher pre-stress may lower the vibrational transmission strength going along the radii to the hub through leaking, as is found with the higher pre-stressed non-sticky spirals in Nephila webs (Wirth \& Barth, 1992; Landolfa \& Barth, 1996; Mortimer et al., 2016). In addition, this prey capture strategy would also retain many of the normal orb spider prey capture behaviours (i.e. respond and reorient to vibrational information from radii and rush out along the radii towards the prey), although behavioural modifications to allow the spider to attack prey not caught up in a web are still required.

\section{Life cycle, dispersal and population genetics}

The cave orb spiders have a complex and unusual life cycle in that they have a mandatory hypogean and a mandatory epigean phase (Smithers, 2005b; Mammola \& Isaia, 2014) (Figure 4). Cocoons are laid relatively close to the cave entrance, in locations experiencing moderate winds, to facilitate the dispersal phase and possibly to wind dry the cocoons to avoid excessive wetting (Mammola \& Isaia, 2014; Chiavazzo et al., 2015). The cocoons have a characteristic tear drop shape with a length of about $30 \mathrm{~mm}$ and hang from the cave ceiling with a $20 \mathrm{~mm}$ long connecting thread (Figure 4). Each cocoon contains about 250 eggs (Eckert \& Moritz, 1992). After several months, the spiderlings hatch and moult into the 2nd instar before emerging from the cocoon. The spiderlings look very different from the adults with a contrasting white and a dark pattern on the abdomen (Pennington, 1979) (Figure 5). They show positive phototaxis, but remain in tight clusters in the 


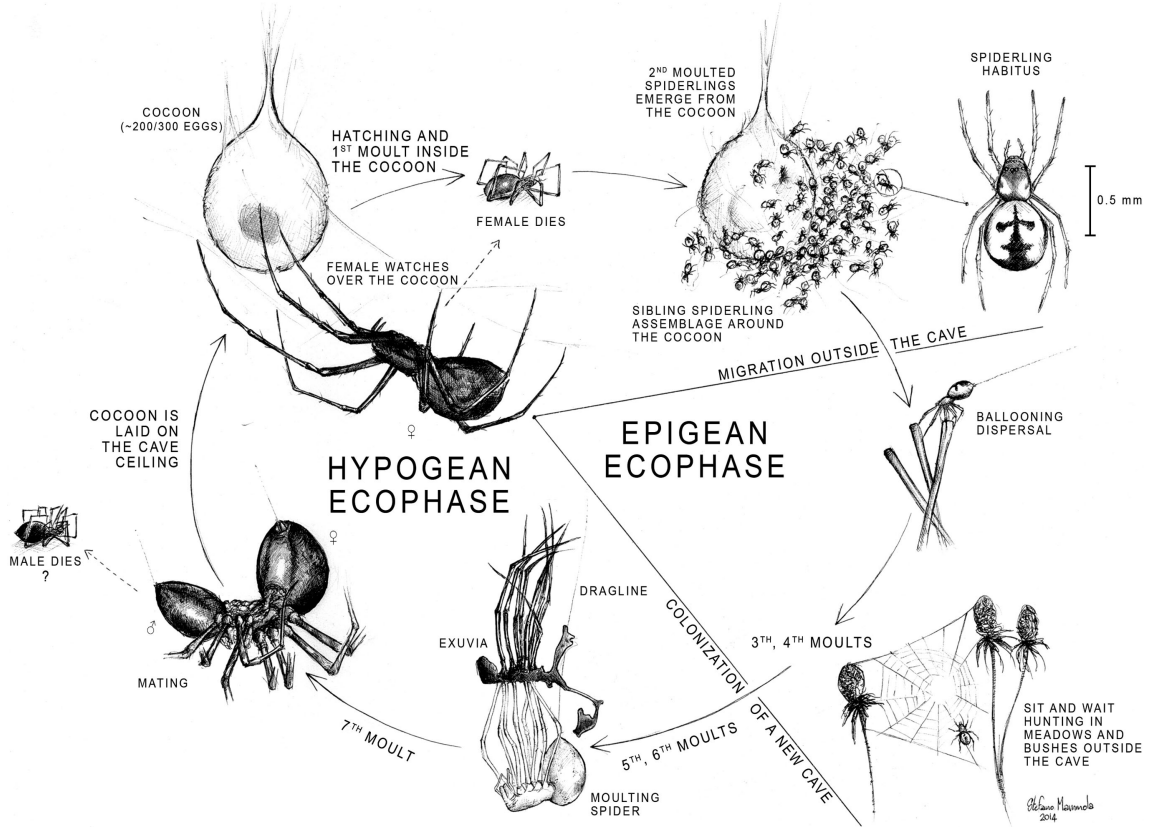

Figure 4. The life-cycle of Meta menardi and Meta bourneti. From Mammola \& Isaia (2014) with permission from Stefano Mammola.

cave entrance zone probably awaiting optimal epigean environmental conditions before dispersing from the cave (McIndoo, 1910; Smithers, 2005b). $M$. menardi spiderlings then spend 1 to 2 months outside, catching prey in orb webs alongside M. merianae and other terrestrial tetragnathids (Pennington, 1979), where they moult once or twice before returning to the cave as subadults. The exact timing of this varies, but in the temperate $M$. menardi, cocoons are usually laid in early summer, hatch in early autumn with the spiderlings leaving the subterranean habitat in early spring (Smithers, 2005b), before returning in the summer. Inside the cave, the subadults undergo a number of further moults before mating. The males probably die relatively soon after mating, although it is not known if they mate once or multiple times with different females. The female matures her eggs and constructs the cocoon, which she guards until her death 2-3 months later (Eckert \& Moritz, 1992).

According to some studies, after leaving the subterranean habitat, $M$. menardi spiderlings disperse by ballooning (Smithers, 2005b; Novak et al., 2010; Mammola \& Isaia, 2014), although this has not been directly observed. 


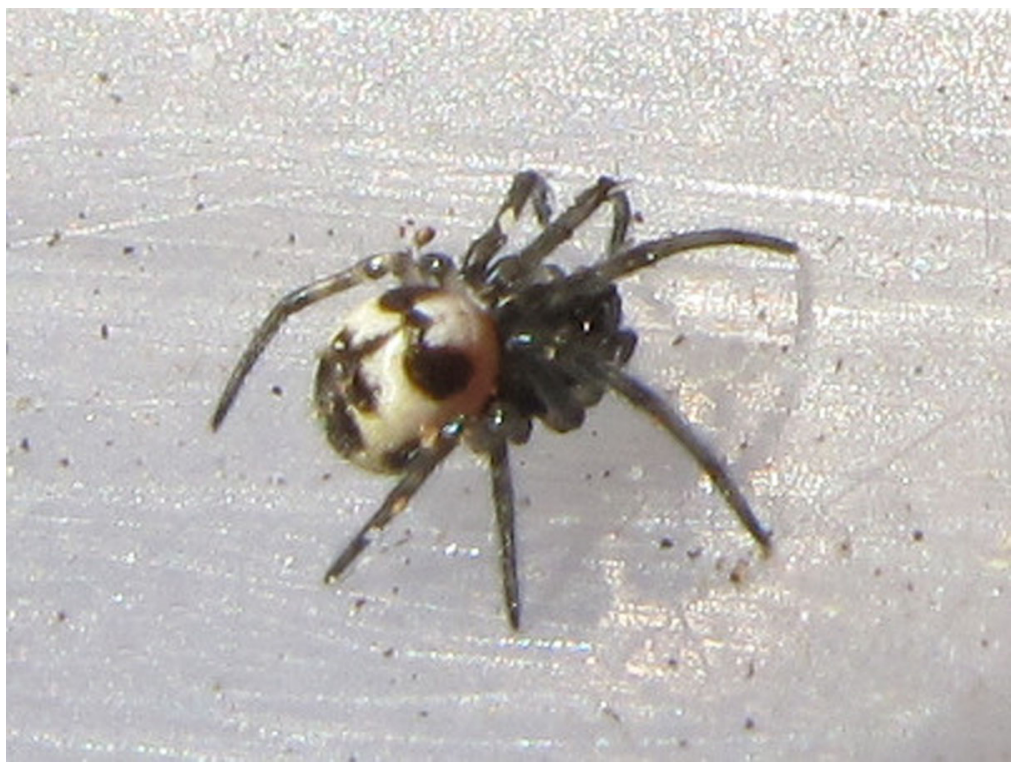

Figure 5. 2nd instar spiderling of Meta menardi. Photo by Didier Petot.

However, juveniles of many species of spiders engage in ballooning to disperse away from siblings and to find new suitable habitats (Foelix, 2011). Ballooning involves the juveniles taking up a specialised tip-toe stance and releasing silk into the air using cues from ambient wind speed and atmospheric electric fields (Weyman, 1993; Morley \& Robert, 2018). Once the silk thread is long enough, wind-induced drag will lift the spider up into the air and carry it significant distances. Spiders have been reported at an altitude of several kilometres and spiders have been found on islands hundreds of kilometres from the mainland (Bell et al., 2005). Ballooning spiders have no control over the direction or length of their dispersal and might land in unsuitable or lethal habitats (Bell et al., 2005). Ballooning is thus a particularly risky strategy for spiders with very narrow habitat requirements such as cave spiders. Given the scattered and relatively sparse occurrence of caves and other large suitable subterranean habitats, how do juvenile Meta spiders find their way back into caves? One solution might be that juveniles do not necessarily have to return to caves. M. menardi adults have reportedly been found in smaller crevices in scree, rocks and possibly hollow trees as well as a range of smaller man-made habitats (Penney \& Ramsey, 1994; Smithers, 2005b; Fritzen \& Kaponen, 2011; Růžička et al., 2013). Although 
such smaller and potentially much more numerous micro-habitats may prove suitable for the development of juveniles into adults, it is unlikely they would allow for reproduction as this would require both a male and a female finding and co-inhabiting these small spaces. Thus natural selection is likely to act against juveniles settling in isolated small dark spaces. Another solution might be that juveniles randomly search for suitable habitats through a combination of walking and ballooning. Some researchers have speculated that the diurnal and seasonal air ventilation in larger caves may allow juveniles to detect the presence of caves (De Freitas et al., 1982; Lunghi et al., 2014), although it is difficult to imagine that this airflow would be detectable from any significant distance by small spiders moving on the ground or in vegetation. It remains a (remote) possibility that this air turnover might suck nearby ballooning spiders into caves, which could potentially be investigated with aerial traps near cave entrances. In any case random searching is likely to have a very low chance of success with a resultant abnormally high spiderling mortality and thus require a large production of juveniles. However, Meta spiders do not lay cocoons with more eggs than other orb spiders of comparable size. One study found that $M$. menardi cocoons have $254 \pm 82$ eggs (Eckert \& Moritz, 1992), while another reported between 300 and 400 eggs per cocoon (Smithers, 2005b). In comparison, one cocoon of Argiope bruennichi had 250 overwintering spiderlings (Bergthaler, 1995) while Argiope aurantia cocoons contain between 300 and 1400 eggs (Hieber, 1992). The most likely answer is therefore that only a small percentage of the juveniles disperse by ballooning with the majority remaining in the vicinity of their natal cave and returning to it after their terrestrial phase (possibly with some never leaving the cave in the first place). The evolution of the terrestrial phase could still be explained by the occasional successful ballooning and by the scarcity of suitable small prey items in the cave habitat (Smithers, 2005a, b). The lack of whole-scale ballooning is further supported by the fact that juveniles in webs have only ever been recorded in the immediate vicinity of suitable subterranean habitats (Fritzen \& Kaponen, 2011), although this could perhaps be explained by sample bias. It is even possible that $M$. bourneti from Mediterranean karst environments do not balloon and possibly never leave the cave environment, as the very arid environment outside the caves is extremely hostile for the spiderlings (C. Ribera, personal communication). 
It is clear that much more research is required into the dispersal phase of Meta spiders in order to evaluate any of the hypotheses mentioned above. However, as juveniles are far too small to carry tracking tags, it remains difficult to directly monitor their movements out of and back in to caves. More indirect methods such as population genetics studies might shed some light on the degree of dispersal (e.g., through gene flow; Slatkin, 1987) between spider populations in neighbouring caves and those further afield. Molecular markers have been used in many arthropod species, including spiders, to deduce effective population sizes and/or population structure (Moya et al., 2004; Vandergast et al., 2004; Flagel et al., 2014; Hjalmarsson et al., 2015; Sappington, 2018; Schwentner \& Giribet, 2018). However, few studies have examined genetic differentiation among orb-weaving spiders (Lee et al., 2004; Kuntner \& Agnarsson, 2011a,b). Troglobiont cave taxa usually occupy narrow distributions and usually exhibit poor dispersal abilities (Trontelj et al., 2009, Juan et al., 2010 and references therein), although the physical characteristics of subterranean habitats may condition the extent of gene flow (Rizzo et al., 2017). Troglophile and trogloxene species, in particular, should in theory exhibit higher levels of gene flow than troglobionts, albeit this is contingent on the ecological requirements and the geographic/climatic characteristics of each species (Caccone, 1985). Allele frequencies and DNA sequence differences among samples collected at different geographic scales are used to estimate gene flow levels to explain the observed patterns. Pairwise $F_{\text {ST }}$ distances are typically used to quantify differentiation between sampled populations (Slatkin, 1987) along with descriptive population parameters such as haplotype $(h)$ and nucleotide $(\pi)$ diversity values, the latter defined as the average number of pairwise differences between DNA sequences (Nei \& Lil, 1979). The fast nucleotide substitution rate of mitochondrial DNA sequences and its maternal inheritance have made these markers particularly popular for these estimations, allowing detection of recent dispersal and vicariant events. Microsatellite DNA markers and, more recently, modern DNA sequencing technologies (next-generation sequencing) can provide genome-wide markers able to be used in phylogeography and population studies (Eaton \& Ree, 2013). In particular, techniques able to scan a reduced representation of the genome, such as restriction-siteassociated DNA sequencing (RADseq) (Miller et al., 2007), genotyping-bysequencing (Elshire et al., 2011) along with several modifications of the two 
original techniques are the most cost-effective approaches (Eaton \& Ree, 2013; Andrews et al., 2016).

Different population structure patterns would be expected depending on the dispersal mechanisms. A dispersal predominantly by ballooning should render a homogenous genetic structure, even at considerable geographical distances, so that low $\mathrm{F}_{\mathrm{ST}}$, haplotype and nucleotide diversity values would be expected for both nuclear and mitochondrial markers. In contrast, a certain amount of population structure may be expected (very low differentiation within cave sites but higher between caves from different regions with isolation-by-distance) if most juveniles return to the natal caves or they essentially remain in their own caves for their entire life-cycle. A sex-biased dispersal model with sedentary females and dispersive males is common in orb spiders (Foellmer \& Fairbairn, 2005; Kasumovic et al., 2007), but there is no evidence of males dispersing out of caves in Meta (Rector, 2009). However, such a behaviour could be detected by molecular ecology methods, as it would give contrasting patterns for mitochondrial and nuclear markers, with the former showing reduced gene flow compared to the latter (Miles et al., 2018).

\section{Conclusion}

The interest in using the subterranean environments and its inhabitants as model systems for studies in ecology and evolutionary biology has been growing in recent years (Culver \& Pipan, 2009; Juan et al., 2010; Juan \& Emerson, 2010; Trontelj et al., 2012; Pipan \& Culver, 2013; Mammola, 2018). This is also true for spiders, where a large number of studies from Central and Southern European subterranean systems have been published (see, for example, Růžička et al., 2013; Manenti et al., 2015; Mammola et al., 2017a; Mammola \& Isaia, 2017). As some of the largest and most conspicuous spiders in caves, Meta spiders have received considerable attention. However, almost all studies focus on ecology, biodiversity and biogeography, but as we have demonstrated in this review, there is a large untapped potential for using Meta as a model organism in behavioural studies as well. Although more quantitative research is needed especially on the non-European Meta, we found good evidence for cave orb spiders showing a number of specific behavioural adaptations to subterranean life. These include an unusual lifehistory, a somewhat modified orb web and potentially a novel prey capture 
strategy involving both on- and off-web foraging. To fully explore the described behaviour, a truly interdisciplinary approach is needed that combines field studies in situ in subterranean habitats with molecular biological techniques and carefully controlled laboratory studies.

To determine the degree to which these behavioural adaptations are unique to cave spiders or alternatively are extensions of the natural behavioural flexibility of orb spiders, more comparative studies between the hypogean Meta spiders and closely related epigean species. A suitable candidate is Metellina menge $i$ with recent studies shedding light on its mating behaviour (Prenter et al., 1994; Bridge et al., 2000), web structure and behavioural flexibility (Tew \& Hesselberg, 2017, 2018), and foraging behaviour (Richards and Hesselberg, data not shown). Even more interesting would be comparisons between hypogean and epigean Meta spiders with at least one species, Meta stridulans, confirmed to be exclusively epigean as it inhabits the laurel forests of Madeira, Portugal, although almost nothing is currently known about its behaviour (Crespo et al., 2014). Obtaining a more detailed understanding of the behaviour and biology of Meta spiders may also shed light on the wider ecological relationship and dynamics of subterranean habitats, since they can potentially be considered an indicator species due to their relative abundance and role as top predators in the twilight zone. Although caves are to some extent shielded from the anthropogenic threats facing many terrestrial habitats, the subterranean habitat is intrinsically linked to what is happening aboveground. A recent study, for example, highlights the extinction risks facing cave spiders from global warming, which, with up to decades delay, also results in warmer subterranean temperatures (Mammola et al., 2017b). Similarly, pesticides, heavy metals and organic pollution can enter the subterranean environment through occasional trogloxene visitors and underground streams (Wood et al., 2008; Medellin et al., 2017; Modrá et al., 2018). Epigean spiders are known to modify their behaviour and orb web geometry in response to pesticides (Samu \& Vollrath, 1992; Benamú et al., 2013; Pasquet et al., 2016) and pesticide and heavy metal pollution can be determined from absorbed residues in spider silk (Samu et al., 1992; Xiao-Li et al., 2006; Tahir et al., 2018). Thus, it is an intriguing possibility that Meta webs and silks can be used as bioassays for assessing wider cave pollution levels. 


\section{Acknowledgements}

The authors would like to thank Lee Knight, Stefano Mammola and Christopher Terrell-Nield for valuable discussions. Didier Petot and Richard McMellon for permission to use their photographs, and Stefano Mammola for permission to use his Meta life-cycle drawing. TH would also like to thank the Department for Biology at the University of the Balearic Islands for funding allowing him to visit.

\section{References}

Ades, C. (1986). A construção de teia geométrica como programa comportamental. — Cién. Cult. 38: 760-775.

Alvarez-Padilla, F. \& Hormiga, G. (2011). Morphological and phylogenetic atlas of the orbweaving spider family Tetragnathidae (Araneae: Araneoidae). — Zool. J. Linn. Soc. 162: 713-879.

Andrews, K.R., Good, J.M., Miller, M.R., Luikart, G. \& Hohenlohe, P.A. (2016). Harnessing the power of RADseq for ecological and evolutionary genomics. - Nature Rev. Genet. 17: 81-92.

Barrantes, G. \& Eberhard, W.G. (2012). Extreme behavioral adjustments by an orb-web spider to restricted space. - Ethology 118: 438-549.

Bell, J.R., Bohan, D.A., Shaw, E.M. \& Weyman, G.S. (2005). Ballooning dispersal using silk: world fauna, phylogenies, genetics and models. — Bull. Entomol. Res. 95: 69-114.

Benamú, M.A., Schneider, M.I., Gonzalez, A. \& Sanchez, N.E. (2013). Short and long-term effects of three neurotoxic insecticides on biological and behavioural attributes of the orb-web spider Alpaida venilae (Araneae, Araneidae): implications for IPM programs. Ecotoxicology 22: 1155-1164.

Bergthaler, G.J. (1995). The cocoon of Argiope bruennichi (Scopoli, 1772) - a SEM study. - In: 15th European collequium of arachnology (Ruzicka, V., ed.). Institute of Entomology, Ceske Budejovice, p. 22-26.

Blamires, S.J. (2010). Plasticity in extended phenotypes: orb web architectural responses to variations in prey parameters. - J. Exp. Biol. 213: 3207-3212.

Bridge, A.P., Elwood, R.W. \& Dick, J.T.A. (2000). Imperfect assessment and limited information preclude optimal strategies in male-male fights in the orb-weaving spider Metellina mengei. — Proc. Roy. Soc. Lond. B: Biol. Sci. 267: 273-279.

Buchli, H.H.R. (1969). Hunting behaviour in the Ctenizidae. - Am. Zool. 9: 175-193.

Caccone, A. (1985). Gene flow in cave arthropods: a qualitative and quantitative approach. Evolution 39: 1223-1235.

Chiavazzo, E., Isaia, M., Mammola, S., Lepore, E., Ventola, L., Asinari, P. \& Pugno, N.M. (2015). Cave spiders choose optimal environmental factors with respect to the generated entropy when laying their cocoon. - Sci. Rep. 5: 7611.

Crespo, L.C., Boieiro, M., Cardoso, P., Aguiar, C.A.S., Amorim, I.R., Barrinha, C., Borges, P.A.V., Menezes, D., Pereira, F., Rego, C., Ribeiro, S., Silva, I.F. \& Serrano, A.R.M. 
(2014). Spatial distribution of Madeira Island Laurisilva endemic spiders (Arachnida: Araneae). - Biodiv. Data J. 2: e1051.

Culver, D.C. \& Pipan, T. (2009). The biology of caves and other subterranean habitats. Oxford University Press, Oxford.

De Freitas, C.R., Littlejohn, R.N., Clarkson, T.S. \& Kristament, I.S. (1982). Cave climate: assessment of airflow and ventilation. - Int. J. Climatol. 2: 383-397.

Denis, J. (1955). Speologica africana: quelques araignées cavernicoles de Guinée française. - Bull. Inst. Fondam. Afr. Noire 17: 1024-1033.

Eaton, D.A.R. \& Ree, R.H. (2013). Inferring phylogeny and introgression using RADseq data: an example from flowering plants (Pedicularis: Orobanchaceae). - Syst. Biol. 62: 689-706.

Eberhard, S.M. (1992). The invertebrate cave fauna of Tasmania: ecology and conservation biology. - MSc thesis, University of Tasmania, Hobart, TAS.

Eberhard, W.G. (1988). Memory of distances and directions moved as cues during temporary spiral construction in the spider Leucauge mariana (Araneae: Araneidae). - J. Insect Behav. 1: 51-66.

Eberhard, W.G. (1990a). Early stages of orb construction by Philoponella vicina, Leucauge mariana and Nephila clavipes (Araneae, Uloboridae and Tetragnathidae) and their phylogenetic implications. - J. Arachnol 18: 205-234.

Eberhard, W.G. (1990b). Function and phylogeny of spider webs. - Annu. Rev. Ecol. Evol. Syst. 21: 341-372.

Eckert, R. \& Moritz, M. (1992). Meta menardi (Latr.) und Meta merianae: Zur Lebensweise und Verbreitung der beiden häufigsten Spinnen in den Höhlen des Harzes, des Kyffhäusers, Thüringens und des Zittauer Gebirges. — Mitt. Zool. Mus. Berlin 68: 345350.

Elshire, R.J., Glaubitz, J.C., Sun, Q., Poland, J.A., Kawamoto, K., Buckler, E.S. \& Mitchell, S.E. (2011). A robust, simple genotyping-by-sequencing (GBS) approach for high diversity species. - PLoS ONE 6: e19379.

Flagel, L.E., Bansal, R., Kerstetter, R.A., Chen, M., Carroll, M., Flannagan, R., Clark, T., Goldman, B.S. \& Michel, A.P. (2014). Western corn rootworm (Diabrotica virgifera virgifera) transcriptome assembly and genomic analysis of population structure. - BMC Genomics 15: 195.

Foelix, R. (2011). Biology of spiders, 3rd edn. - Oxford University Press, Oxford.

Foellmer, M.W. \& Fairbairn, D.J. (2005). Selection on male size, leg length and condition during mate search in a sexually highly dimorphic orb-weaving spider. - Oecologia 142: 653-662.

Fritzén, N.R. \& Koponen, S. (2011). The cave spider Meta menardi (Araneae, Tetragnathidae) - occurrence in Finland and notes on its biology. — Mem. Soc. Fauna Flora Fenn. 87: 80-86.

Harmer, A.M.T., Kokko, H., Herberstein, M.E. \& Madin, J.S. (2012). Optimal web investment in sub-optimal foraging conditions. - Naturwissenschaften 99: 65-70. 
Harwood, J.D., Sunderland, K.D. \& Symondsen, W.O.C. (2005). Monoclonal antibodies reveal the potential of the tetragnathid spider Pachygnatha degeeri (Araneae: Tetragnathidae) as an aphid predator. - Bull. Entomol. Res. 95: 161-167.

Heiling, A.M. \& Herberstein, M.E. (1999). The role of experience in web-building spiders (Araneidae). - Anim. Cogn. 2: 171-177.

Hénaut, Y., Machkour-M'Rabat, S. \& Lachaud, J.-P. (2014). The role of learning in riskavoidance strategies during spider-ant interactions. - Anim. Cogn. 17: 185-195.

Hénaut, Y., Pablo, J., Ibarra-Nuñez, G. \& Williams, T. (2001). Retention, capture and consumption of experimental prey by orb-web weaving spiders in coffee plantations of Southern Mexico. - Entomol. Exp. Appl. 98: 1-8.

Hesselberg, T. (2013). Web-building flexibility differs in two spatially constrained orb spiders. - J. Insect Behav. 26: 283-303.

Hesselberg, T. (2015). Exploration behaviour and behavioural flexibility in orb-web spiders: a review. - Cur. Zool. 61: 313-327.

Hesselberg, T. \& Vollrath, F. (2006). Temperature affects both web spider response time and prey escape speed. - Bull. Br. Arachnol. Soc. 13: 275-280.

Hieber, C.S. (1992). Spider cocoons and their suspension systems as barriers to generalist and specialist predators. - Oecologia 91: 530-535.

Hjalmarsson, A.E., Bergsten, J. \& Monaghan, M.T. (2015). Dispersal is linked to habitat use in 59 species of water beetles (Coleoptera: Adephaga) on Madagascar. — Ecography 38: 732-739.

Japyassu, H.F. \& Laland, K.N. (2017). Extended spider cognition. — Anim. Cogn. 20: 375395.

Juan, C. \& Emerson, B.C. (2010). Evolution underground: shedding light on the diversification of subterranean insects. - J. Biol. 9: 17.

Juan, C., Guzik, M.T., Jaume, D. \& Cooper, S.J.B. (2010). Evolution in caves: Darwin's 'wreck of ancient life' in the molecular era. — Mol. Ecol. 19: 3865-3880.

Kallal, R.J. \& Hormiga, G. (2018). An expanded molecular phylogeny of metaine spiders (Aranea, Tetragnathidae) with new description of new taxa from Taiwan and the Philippines. - Invertebr. Syst. 32: 400-422.

Kasumovic, M.M., Bruce, M.J., Herberstein, M.E. \& Andrade, M.C.B. (2007). Risky mate search and mate preference in the golden orb-web spider (Nephila plumipes). - Behav. Ecol. 18: 189-195.

Klärner, D. \& Barth, F.G. (1982). Vibratory signals and prey capture in orb-weaving spiders (Zygiella x-notata, Nephila clavipes; Araneidae). — J. Comp. Physiol. 148: 445-455.

Krink, T. \& Vollrath, F. (2000). Optimal area use in orb webs of the spider Araneus diadematus. - Naturwissenschaften 87: 90-93.

Kuntner, M. \& Agnarsson, I. (2011a). Phylogeography of a successful aerial disperser: the golden orb spider Nephila on Indian Ocean islands. - BMC Evol. Biol. 11: 119.

Kuntner, M. \& Agnarsson, I. (2011b). Biogeography and diversification of hermit spiders on Indian Ocean islands (Nephilidae: Nephilengys). — Mol. Phylogenet. Evol. 59: 477-488.

Landolfa, M.A. \& Barth, F.G. (1996). Vibrations in the orb web of the spider Nephila clavipes: cues for discrimination and orientation. - J. Comp. Physiol. 179: 493-508. 
Lee, J.W., Jiang, L., Su, Y.C. \& Tso, I.M. (2004). Is Central Mountain Range a geographic barrier to the giant wood spider Nephila pilipes (Araneae: Tetragnathidae) in Taiwan? A population genetic approach. - Zool. Stud. 43: 112-122.

Liao, C.-P., Chi, K.-J. \& Tso, I.-M. (2009). The effects of wind on trap structural and material properties of a sit-and-wait predator. — Behav. Ecol. 20: 1194-1203.

Lin, L.H., Edmonds, D.T. \& Vollrath, F. (1995). Structural engineering of an orb-spider's web. - Nature 373: 146-148.

Lunghi, E., Manenti, R. \& Ficetola, G.F. (2014). Do cave features affect underground habitat exploitation by non-troglobite species? - Acta Oecol. 55: 29-35.

Madsen, M., Terkildssen, S. \& Toft, S. (2004). Microcosm studies on control of aphids by generalist arthropod predators: effects of alternative prey. - BioControl 49: 483-504.

Mammola, S. (2017). Modelling the future spread of native and alien congeneric species in subterranean habitats - the case of meta cave-dwelling spiders in Great Britain. - Int. J. Speleol. 46: 427-437.

Mammola, S. (2018). Finding answers in the dark: caves as models in ecology fifty years after poulson and white. - Ecography 41: 1-21.

Mammola, S., Cardoso, P., Ribera, C., Pavlek, M. \& Isaia, M. (2017a). A synthesis on cavedwelling spiders in Europe. - J. Zool. Syst. Evol. Res. 56: 1-16.

Mammola, S., Goodacre, S.L. \& Isia, M. (2017b). Climate change may drive cave spiders to extinction. - Ecography 40: 1-10.

Mammola, S. \& Isaia, M. (2014). Niche differentiation in Meta bourneti and M. menardi (Aranea, Tetragnathidae) with notes on the life history. — Int. J. Speleol. 43: 343-353.

Mammola, S. \& Isaia, M. (2017). Spiders in caves. — Proc. Roy. Soc. Lond. B: Biol. Syst. 284: 20170193.

Mammola, S. \& Isaia, M. (2018). Day-night and seasonal variations of a subterranean invertebrate community in the twilight zone. - Subterr. Biol. 27: 31-51.

Manenti, R., Lunghi, E. \& Ficetola, G.F. (2015). The distribution of cave twilight-zone spiders depends on microclimatic features and trophic supply. — Invertebr. Biol. 134: 242-251.

Marusik, Y.M. \& Larsen, N. (2018). A synopsis of African Metellina (Aranei, Tetragnathidae, Metainae) with description of a new species from South Africa. — Vestnik Zool. 52: 205216.

McIndoo, N.E. (1910). Biology of the shawnee cave spiders. — Biol. Bull. 19: 303-323.

Medellin, R.A., Wiederholt, R. \& Lopez-Hoffmann, L. (2017). Conservation relevance of bat caves for biodiversity and ecosystem services. - Biol. Cons. 211: 45-50.

Meek, B., Loxton, D., Sparks, T., Pywell, R., Pickett, H. \& Nowakowski, M. (2002). The effect of arable field margin composition on invertebrate biodiversity. - Biol. Cons. 106: 259-271.

Miles, L.S., Dyer, R.J. \& Verrelli, B.C. (2018). Urban hubs of connectivity: contrasting patterns of gene flow within and among cities in the Western black widow spider. Proc. Roy. Soc. Lond. B: Biol. Sci. 285: 20181224. 
Miller, M.R., Dunham, J.P., Amores, A., Cresko, W.A. \& Johnson, E.A. (2007). Rapid and cost-effective polymorphism identification and genotyping using restriction site associated DNA (RAD) markers. — Genome Res. 17: 240-248.

Modrá, H., Gruberová, E., Konečný, O., Ulmann, V., Kaucká, P., Vlková, M., Tůma, A., Halešová, T., Kudělka, J., Geršl, M. \& Pavlík, I. (2018). Influx and concentration of triazine pesticides in the Amaterska cave system, Moravian Karst, Czech Republic. J. Soils Sedim. 18: 640-647. DOI:10.1007/s11368-017-1831-0.

Morley, E.L. \& Robert, D. (2018). Electric fields elicit ballooning in spiders. - Curr. Biol. 28: 2324-2330.

Mortimer, B., Soler, A., Saviour, C.R., Zaera, R. \& Vollrath, F. (2016). Tuning the instrument: sonic properties in the spider's web. - J. Roy. Soc. Interf. 13: 20160341.

Moya, Ó., Contreras-Díaz, H.G., Oromí, P. \& Juan, C. (2004). Genetic structure, phylogeography and demography of two ground-beetle species endemic to the Tenerife laurel forest (Canary Islands). — Mol. Ecol. 13: 3153-3167.

Nakata, K. (2013). Spatial learning affects thread tension control in orb-webs. - Biol. Lett. 9: 20130052.

Nei, M. \& Li, W.H. (1979). Mathematical model for studying genetic variation in terms of restriction endonucleases. — Proc. Natl. Acad. Sci. USA 76: 5269-5273.

Nentwig, W. (1982). Why do only certain insects escape from a spider's web? - Oecologia 53: 412-417.

Nentwig, W., Blick, T., Gloor, D., Hänggi, A. \& Kropf, C. (2018). Araneae - Spiders of Europe. Version 09.2018. Available online at https://www.araneae.nmbe.ch, accessed on 04/09/2018. DOI:10.24436/1.

Novak, T., Tkavc, T., Kuntner, M., Arnett, A.E., Delakorde, S.L., Perc, M. \& Janzekovic, F. (2010). Niche partitioning in orbweaving spiders Meta menardi and Metellina merianae (Tetragnathidae). - Acta Oecol 36: 522-529.

Pasquet, A., Ridwan, A. \& Leborgne, R. (1994). Presence of prey affects web-building in an orb-weaving spider Zygiella x-notata. — Anim. Behav. 47: 477-480.

Pasquet, A., Anotaux, M. \& Leborgne, R. (2011). Loss of legs: is it or not a handicap for an orb-weaving spider? - Naturwissenschaften 98: 557-564.

Pasquet, A., Tupinier, N., Mazzia, C. \& Capowiez, Y. (2016). Exposure to spinosad affects orb-web spider (Agalenatea redii) survival, web construction and prey capture under laboratory conditions. — J. Pest. Sci. 89: 507-515.

Penney, D. \& Ramsey, J. (1994). A Meta menardi (Latreille) up a tree. — Newsl. Br. Arachnol. Soc. 70.

Pennington, B.J. (1979). The colour patterns of diurnal Meta menardi (Latreille). — Bull. Br. Arachnol. Soc. 4: 392-393.

Pipan, T. \& Culver, D. (2013). Forty years of epikarst: what biology have we learned? — Int. J. Speleol. 42: 215-223.

Poulson, T.L. \& White, W.B. (1969). The cave environment. — Science 165: 971-981.

Prenter, J., Elwood, R.W. \& Colgan, S. (1994). The influence of prey size and female reproductive state on courtship of the autumn spider, Metellina segmentata: a field experiment. - Anim. Behav. 47: 449-456. 
Rector, M.A. (2009). Foraging in the cave environment: the ecology of the cave spider Meta ovalis (Araneae: Tetragnathidae). - M.S. Thesis. The Ohio State University, Columbus, $\mathrm{OH}$.

Rizzo, V., Sánchez-Fernández, D., Alonso, R., Pastor, J. \& Ribera, I. (2017). Substratum karstificability, dispersal and genetic structure in a strictly subterranean beetle. - J. Biogeogr. 44: 2527-2538.

Robinson, M.H., Mirsck, M. \& Turner, O. (1969). The predatory behavior of some areneid species and the origin of immobilization wrapping. — Psyche 70: 487-501.

Rodríguez, R.L., Briceño, R.D., Briceño-Aguilar, E. \& Höbel, G. (2015). Nephila clavipes spiders (Araneae: Nephilidae) keep track of captured prey counts: testing for a sense of numerosity in an orb-weaver. - Anim. Cogn. 18: 307-314.

Rodríguez, R.L. \& Gamboa, S.E. (2000). Memory of captured prey in three web spiders (Araneae: Araneidae, Linyphiidae and Tetragnathidae). - Anim. Cogn. 3: 91-97.

Rodríguez, R.L., Kolodziej, R.C. \& Höbel, G. (2013). Memory of prey larders in golden orb-web spiders, Nephila clavipes (Araneae: Nephilidae). — Behaviour 150: 1345-1356.

Růžička, V., Ŝmilauer, P. \& Mlejnek, R. (2013). Colonization of subterranean habitats by spiders in Central Europe. - Int. J. Speleol. 42: 133-140.

Sahni, V., Blackledge, T.A. \& Dhinojwala, A. (2010). Viscoelastic solids explain spider web stickiness. - Nature Commun. 1: 1-4.

Samu, F., Matthews, G.A., Lake, D. \& Vollrath, F. (1992). Spider webs are efficient collectors of agrochemical spray. - Pest. Sci. 36: 47-51.

Samu, F. \& Vollrath, F. (1992). Spider orb web as bioassay for pesticides side effects. Entomol. Exp. Appl. 62: 117-124.

Sappington, T.W. (2018). Migratory flight of insect pests within a year-round distribution: European corn borer as a case study. - J. Integr. Agricult. 17: 1485-1505.

Schenkel, E. (1936). Schwedisch-chinesische wissenschaftliche Expedition nach den nordwestlichen Provinzen Chinas, unter Leitung von Dr Sven Hedin und Prof. Sü Ping-chang. Araneae gesammelt vom schwedischen Artz der Exped. — Arkiv för Zoologi 29: 1-314.

Schwentner, M. \& Giribet, G. (2018). Phylogeography, species delimitation and population structure of a Western Australian short-range endemic mite harvestman (Arachnida: Opiliones: Pettalidae: Karripurcellia). — Evol. Syst. 2: 81-87.

Sensenig, A., Agnarsson, I. \& Blackledge, T.A. (2010). Behavioural and biomaterial coevolution in spider orb webs. - J. Evol. Biol. 23: 1839-1856.

Sensenig, A.T., Lorentz, K.A., Kelly, S.P. \& Blackledge, T.A. (2012). Spider orb webs rely on radial threads to absorb prey kinetic energy. - J. Roy. Soc. Interf. 9: 1880-1891.

Sket, B. (2008). Can we agree on an ecological classification of subterranean animals? J. Nat. Hist. 42: 1549-1563.

Slatkin, M. (1987). Gene flow and the geographic structure of natural populations. - Science 236: 787-792.

Smithers, P. (1996). Observations on the prey of the cave spider Meta menardi (Latreille, 1804). - Newsletter of the British Arachnological Society 77: 12-14.

Smithers, P. (2005a). The diet of the cave spider Meta menardi (Latreille 1804) (Araneae, Tetragnathidae). - J. Arachnol. 33: 243-246. 
Smithers, P. (2005b). The early life history and dispersal of the cave spider Meta menardi (Latreille, 1804) (Araneae: Tetragnathidae). — Bull. British Arachnol. Soc. 13: 213-216.

Swanson, B.O., Blackledge, T.A. \& Hayashi, C.Y. (2007). Spider capture silk: performance, implications of variation in an exceptional biomaterial. - J. Exp. Zool. 307A: 654-666.

Tahir, H.M., Aamir, H. \& Nadeem, J. (2018). Use of spider webs as indicators of air quality assessment of Lahore City. — Water Environ. J. 32: 292-300.

Tew, E.R., Adamson, A. \& Hesselberg, T. (2015). The web repair behaviour of an orb spider. - Anim. Behav. 103: 137-146.

Tew, N. \& Hesselberg, T. (2017). The effect of wind exposure on the web characteristics of a Tetragnathid orb spider. — J. Insect. Behav. 30: 273-286.

Tew, N. \& Hesselberg, T. (2018). Web asymmetry in the tetragnathid orb spider Metellina mengei (Blackwell, 1869) is determined by web inclination and web size. — J. Arachnol. 46: 370-372.

Trontelj, P., Blejec, A. \& Fišer, C. (2012). Ecomorphological convergence of cave communities. - Evolution 66: 3852-3865.

Trontelj, P., Douady, C.J., Fišer, C., Gibert, J., Gorički, Š., Lefébure, T., Sket, B. \& Zakšek, V. (2009). A molecular test for cryptic diversity in ground water: how large are the ranges of macro-stygobionts? — Freshw. Biol. 54: 727-744.

Turner, J., Vollrath, F. \& Hesselberg, T. (2011). Wind speed affects prey-catching behaviour in an orb web spider. - Naturwissenschaften 98: 1063-1069.

Vandergast, A.G., Gillespie, R.G. \& Roderick, G.K. (2004). Influence of volcanic activity on the population genetic structure of Hawaiian Tetragnatha spiders: fragmentation, rapid population growth and the potential for accelerated evolution. - Mol. Ecol. 13: 17291743.

Vollrath, F. (1987). Altered geometry of webs in spiders with regenerated legs. — Nature 328: 247-248.

Vollrath, F., Downes, M. \& Krackow, S. (1997). Design variability in web geometry of an orb-weaving spider. — Physiol. Behav. 62: 735-743.

Vollrath, F. \& Selden, P. (2007). The role of behavior in the evolution of spiders, silks and webs. - Annu. Rev. Ecol. Evol. Syst. 38: 819-846.

Weyman, G.S. (1993). A review of the possible causative factors and significance of ballooning in spiders. — Ethol. Ecol. Evol. 5: 279-291.

Wirth, E. \& Barth, F.G. (1992). Forces in the spider orb web. — J. Comp. Physiol. A. 171: 359-371.

Wood, P.J., Gunn, J. \& Dunn, S.D. (2008). Response of benthic cave invertebrates to organic pollution events. - Aquat. Conserv. 18: 909-922.

World Spider Catalog (2018). World Spider Catalog. Version 19.5. Natural History Museum Bern, Bern. Available online at http://wsc.nmbe.ch. DOI:10.24436/2. (accessed 4 September 2018).

World Spider Catalog (2019). World Spider Catalog. Version 20.0. Natural History Museum Bern, Bern. Available online at http://wsc.nmbe.ch. DOI:10.24436/2. (accessed 9 May 2019). 
Wu, C.-C., Blamires, S.J., Wu, C.-L. \& Tso, I.-M. (2013). Wind induces variations in spider web geometry and sticky spiral droplet volume. - J. Exp. Biol. 216: 3342-3349.

Xiao-Li, S., Yu, P., Hose, G.C., Jian, C. \& Feng-Xiang, L. (2006). Spider webs as indicators of heavy metal pollution in air. - Bull. Environ. Contam. Toxicol. 76: 271-277.

Yoshida, M. \& Shinkai, A. (1993). Predatory behavior and web structure of Meta menardi (Araneae: Tetragnathidae). - Acta Arachnol. 42: 21-25.

Zaera, R., Soler, A. \& Teus, J. (2014). Uncovering changes in spider orb-web topology owing to aerodynamic effects. — J. Roy. Soc. Interf. 11: 20140484.

Zschokke, S. (2000). Form and function of the orb-web. - In: Proceedings of the 19th European colloquium of arachnology (Toft, S. \& Scharff, N., eds). Aarhus University Press, Århus, p. 99-106.

Zschokke, S. \& Herberstein, M.E. (2005). Laboratory methods for maintaining and studying web-building spiders. - J. Arachnol. 33: 205-213.

Zschokke, S. \& Vollrath, F. (1995). Web construction patterns in a range of orb-weaving spiders (Araneae). — Eur. J. Entomol. 92: 523-541. 